\title{
Temporal scour evolution at non-uniform bridge piers
}

\section{Giuseppe Oliveto PhD}

Associate Professor, School of Engineering, University of Basilicata,

Potenza, Italy (corresponding author: giuseppe.oliveto@unibas.it)

\section{Maria Cristina Marino}

PhD Student, School of Engineering, University of Basilicata, Potenza, Italy

Scour at uniform cylindrical piers has received considerable attention in the past. However, bridge foundations can be subjected to the flow due to single or combined effects of long-term riverbed degradation, lateral shifting of the stream, contraction scour, local scour or other factors. This paper focuses on bed morphology changes due to local scour at piers founded on piles or caissons when the foundation is located at the initial bed level. Experiments were carried out in a $1 \mathrm{~m}$ wide $\mathbf{2 0} \mathrm{m}$ long rectangular channel under clear-water and steady flow conditions. The majority of runs were of long duration in order to guarantee sufficient interaction between the flow and pier foundation and to approach the equilibrium phase. Two nearly uniform bed sediments were considered to assess grain size effects. The experimental data obtained provided new information on the temporal variation of scour depth, the areal extent of the scour hole and the scour volume, which are useful for validation of advanced numerical models. In this paper, scour depths are compared with the HEC-18 approach and agreements appear suitable only at the equilibrium phase. Moreover, scour progress is compared to that of uniform cylindrical piers and foundation effects are emphasised. A generalised scour equation is proposed, accounting for such effects.

\section{Notation}

D pier column diameter (m)

$D_{\mathrm{C}} \quad$ circular caisson diameter $(\mathrm{m})$

$D_{\text {eq }} \quad$ equivalent pier diameter (m)

$d_{50} \quad$ median grain size $(\mathrm{m})$

$d_{\mathrm{P}} \quad$ pile foundation diameter (m)

$F_{d} \quad$ densimetric Froude number

$\mathrm{F}_{\mathrm{di}} \quad$ inception densimetric Froude number

$F_{t} \quad$ threshold Froude number

$\boldsymbol{g}$ gravitational acceleration $\left(\mathrm{m} / \mathrm{s}^{2}\right)$

$g^{\prime}$ approach flow depth (m) downstream edge of scour hole (m) edge of scour hole $(\mathrm{m})$ approach discharge $\left(\mathrm{m}^{3} / \mathrm{s}\right)$ coefficient of determination spacing of foundation piles $(\mathrm{m})$ dimensionless time foundation (m) pile cap thickness (m) time (s) cross-sectional flow velocity $(\mathrm{m} / \mathrm{s})$ (square) pile cap width (m) cylindrical pier modified gravitational acceleration $\left(\mathrm{m} / \mathrm{s}^{2}\right)$ scour hole length from pier vertical axis to scour hole length from pier vertical axis to upstream characteristic dimensionless time accounting for foundation top elevation from the initial bed level (m) dimensionless scour depth for uniform dimensionless scour depth for non-uniform pier maximum scour depth at given time $t$ for uniform cylindrical pier (m) maximum scour depth at given time $t$ for non-uniform pier (m) scour depth at the rear of foundation (m) scour depth at the front of foundation (m) coefficient dimensionless group $Z^{*} /\left[\left(D_{\mathrm{C}} / D\right) \sigma^{-0.5} \mathrm{~F}_{\mathrm{d}}^{1 \cdot 5}\right]$ or $Z^{*} /\left[\left(W_{\mathrm{PC}} / D\right) \sigma^{-0.5} \mathrm{~F}_{\mathrm{d}}^{1 \cdot 5}\right]$

$\Lambda \quad$ scour hole volume at given time $t\left(\mathrm{~m}^{3}\right)$

$\rho \quad$ mass density of water $\left(\mathrm{kg} / \mathrm{m}^{3}\right)$

$\rho_{\mathrm{s}} \quad$ mass density of sediment grains $\left(\mathrm{kg} / \mathrm{m}^{3}\right)$

$\sigma \quad$ sediment gradation coefficient

$\psi_{\text {HEC-18 ratio of computed to observed scour depths according }}$ to HEC-18 methodology (Arneson et al., 2012)

$\psi_{\mathrm{OH}} \quad$ ratio of computed to observed scour depths according to the formula of Oliveto and Hager (2002)

\section{Introduction}

Most existing equations for predicting local scour at bridge piers apply to piers with a constant cross-sectional dimension for the full length of the pier, usually called uniform piers (Melville and Raudkivi, 1996). However, actual bridge piers frequently behave as non-uniform piers. Pier footings can often project above the streambed as a result of long-term degradation, lateral shifting of the stream, contraction scour or local scour during a runoff event. In these cases, the effects of nonuniformity of the pier footing geometry should be incorporated into the analysis of local scour processes. Figure 1 shows examples of local scour around a pier founded on piles. 


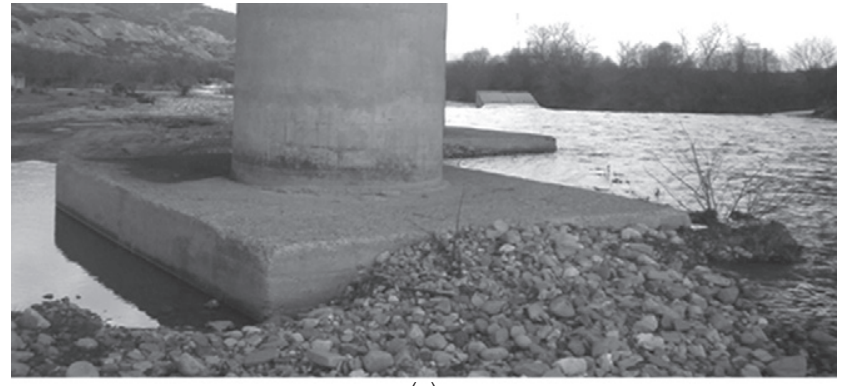

(a)

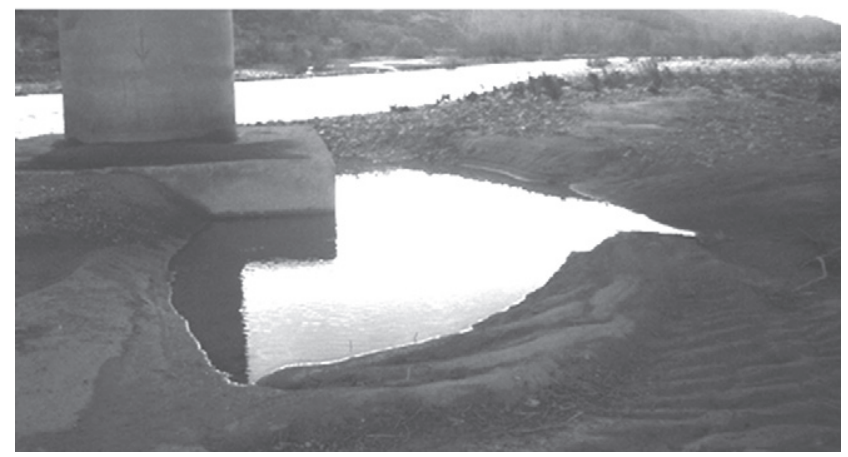

(b)

Figure 1. Local scour at a bridge pier with pile cap at floodplain elevation (Basento River, Italy): (a) view from upstream; (b) view from downstream

An early experimental study on local scour at non-uniform piers was made by Chabert and Engeldinger (1956). They conducted laboratory tests considering a cylindrical pier founded on a larger cylindrical caisson and found that footings reduced local scour depths if they were of sufficient area (e.g. when the caisson diameter was three times the pier diameter) and when the top of the caisson was kept below the bed level. Jones et al. (1992) carried out a laboratory study to investigate the effects of footing location on the depth of scour at the Baldwin Bridge in Connecticut. They observed significant arresting effects of scour caused by footings at or below the initial bed level. However, Melville (1993) and Jones et al. (1993) remarked that prudent bridge design should attempt to avoid setting the footing location near the streambed at the time of construction, mainly because general bed degradation could expose the footing and lead to increased local scour. Parola et al. (1996) showed the effect of rectangular foundations over the whole range of possible pier to foundation width ratios and through the whole range of foundation elevations. They examined the effect of an upstream foundation extension on the scour depth. The study by Jones et al. (1992) revealed that the foundation alleviated scour when placed at or below the streambed, and a method for predicting the potential maximum scour was presented. Melville and Raudkivi (1996) carried out an experimental investigation into local scour at non-uniform cylindrical piers comprising a cylinder of diameter $D$ founded on a larger cylinder. They introduced the concept of the effective pier diameter - the diameter of a uniform pier that would induce the same scour depth as the actual non-uniform pier for the same flow and sediment. Martín-Vide et al. (1998) considered local scour at rectangular bridge piers founded on two cylindrical piles, where the pier-piling interface was set at different elevations with respect to the bed. All the tests lasted $4 \mathrm{~h}$ and were carried out under the same approach flow condition. Melville and Coleman (2000) suggested a conservative method to predict local scour at piers founded on pile groups by considering complex piers as columns founded on caissons. Coleman (2005) presented a new methodology to predict local scour depth at piers founded on piles. The method distinguishes the relative scouring potential of the components of complex piers and the transition of scouring at different pile cap elevations. Sheppard and Glasser (2009) developed predictive equations for both simple and complex piers based on clearwater and live-bed experiments conducted in several laboratories in the USA and New Zealand. Ataie-Ashtiani et al. (2010) carried out 70 experiments with rectangular piers founded on piles or caissons, and found that the pile cap protected the bed from scour and postponed the start of the scour process when it was located at bed level. Amini et al. (2011) investigated the effects of pile caps on local scour by means of experiments under a clear-water regime with varying pile cap dimensions and its elevation from the initial streambed. $\mathrm{Lu}$ et al. (2011) proposed a semi-empirical model to estimate the temporal variation of scour depth at non-uniform piers with unexposed foundations using the concept of primary vortex and sediment transport theory. The model was also extended to unsteady flows under a clear-water regime. Veerappadevaru et al. (2011) introduced a method to predict the equilibrium scour depth around caisson piers based on the power concept of the primary vortex. The width of the caisson was twice that of the cylindrical pier. Kothyari and Kumar (2012) updated the method of Kothyari et al. (1992) to predict the temporal variation of scour depth at compound piers. Reasonably good agreement was found between observed and computed values for not only their own data, but other published data as well. Kumar and Kothyari (2012) presented some experimental observations on flow patterns and turbulence characteristics within the developing scour hole around a circular compound pier with the top surface of the foundation placed at different elevations from the bed level. The design procedure for non-uniform piers in the USA is given in report HEC-18 (Arneson et al., 2012). According to this procedure, the equilibrium scour depth is estimated by a superposition approach based on separation of the pier components and determination of the respective scour depths. Chang et al. (2013) studied flow and turbulence structures at piers for which only part of the foundation was exposed to the flow. The results showed very complex distributions and large-scale temporal oscillations of the bed friction velocity. Ferraro et al. (2013) considered the effects of pile cap thickness. The observed maximum scour depths varied with pile cap thickness and were greater for thicker pile cap values when piling was 
either completely into the flow, partially buried or completely buried slightly below the initial bed level. Amini et al. (2014) carried out an experimental investigation under clear-water conditions considering complex piers. They found that predicting methods based on superposition of scour depths at the piles, pile cap and pier column would provide inadequate estimates of total scour depth in many cases. Finally, Moreno et al. (2016) performed an experimental campaign of 25 longduration laboratory tests exploring different relationships between the pier stem and the pile cap width as well as different initial foundation exposures.

Although the studies are numerous, the research to date has a number of shortcomings.

- The majority of literature studies consider superposition approaches, comprising a conceptual separation of the pier components and determination of the respective scour depths for the individual components. These approaches are quite complicated and suffer from conceptual and practical limitations (Coleman, 2005).

- The majority of predictive equations were developed for equilibrium scour conditions, and estimate the maximum scour depth or the scour depth at the pier footing front. However, equilibrium scour depths are often only appropriate for live-bed conditions. Conversely, equilibrium scour depths are typically overly conservative where clear-water conditions exist.

- There are very few reported studies on the bed morphology features around complex piers. It is usually assumed that the shape of the scour hole can be approximated by an inverted cone frustum with the slope corresponding to the sediment's angle of repose, but this hypothesis has proven to be adequate only for simple cylindrical piers and has not been verified for complex piers (Chreties et al., 2013).

Based on a number of laboratory experiments, some of which were of long duration, this paper aims to provide a more comprehensive analysis of the temporal and spatial evolution of the local bed morphology at non-uniform piers comprising piers founded on either piles or caissons. A new predictive approach, which is an extension of the formula given by Oliveto and Hager (2002) for local scour at uniform piers, is proposed to overcome the drawbacks of superposition approaches. The effect of time is considered and the temporal development of local scour depth under clear-water conditions is analysed. Finally, experimental data on the main characteristics of the scour hole geometry are provided. This information could also be useful for the validation of advanced numerical models. Because of the significant experimental efforts required to obtain detailed surveys, this paper only considers the case (often encountered in practice) where the top surface of the foundation is placed at the bed level. However, the proposed approach also appears to be promising for different elevations of the foundation from the streambed.

\section{Experiments}

Experiments were performed in a $1 \mathrm{~m}$ wide, $1 \mathrm{~m}$ deep and $20 \mathrm{~m}$ long rectangular straight channel at the University of Basilicata, Italy. Two complex pier models were tested. One model was a pile-founded pier consisting of a cylindrical column of diameter $D=0.12 \mathrm{~m}$, a square pile cap of width $W_{\mathrm{PC}}=0.24 \mathrm{~m}$ and thickness $T_{\mathrm{PC}}=0.08 \mathrm{~m}$, and four cylindrical piles of diameter $d_{\mathrm{P}}=0.04 \mathrm{~m}$, spaced from each other by $S_{\mathrm{P}}=0.12 \mathrm{~m}$. This model reproduced a typical pier on the River Basento, Italy, at a scale of 1:25. The other model was a caisson-founded pier consisting of a cylindrical column of diameter $D=0.10 \mathrm{~m}$ founded on a larger cylinder of diameter $D_{\mathrm{C}}=0.22 \mathrm{~m}$. Definition sketches are provided in Figure 2.

The dimensions of the models were selected to allow welldeveloped scour holes while keeping channel contraction effects insignificant. Two bed sediments were tested using either nearly uniform sand of density $\rho_{\mathrm{s}}=2650 \mathrm{~kg} / \mathrm{m}^{3}$, median grain size $d_{50}=1.7 \mathrm{~mm}$ and sediment gradation $\sigma=\left(d_{84} / d_{16}\right)^{1 / 2}=1.5$ or nearly uniform gravel with $\rho_{\mathrm{s}}=2650 \mathrm{~kg} / \mathrm{m}^{3}, d_{50}=9.0 \mathrm{~mm}$ and $\sigma=1 \cdot 5$. The gravel was mainly used to better recognise grain size effects. However, this experimental bed sediment would correspond to natural gravel-cobble riverbeds (where clear-water conditions typically exist also during floods) according to Froude's similarity law. The mobile bed was $15 \mathrm{~m}$ long to guarantee fully developed flow and $0 \cdot 4 \mathrm{~m}$ deep. The undisturbed bed surface was horizontal and the pier model was always reset to the initial bed level by flushing the top of the foundation.

All experiments were performed under steady flow conditions and a clear-water regime with the exception of one run (PP9)

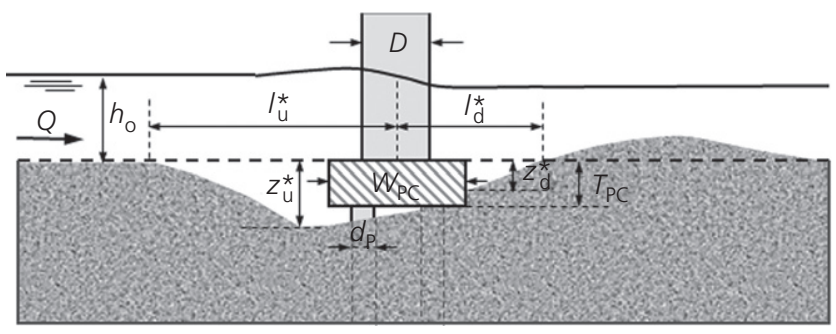

(a)

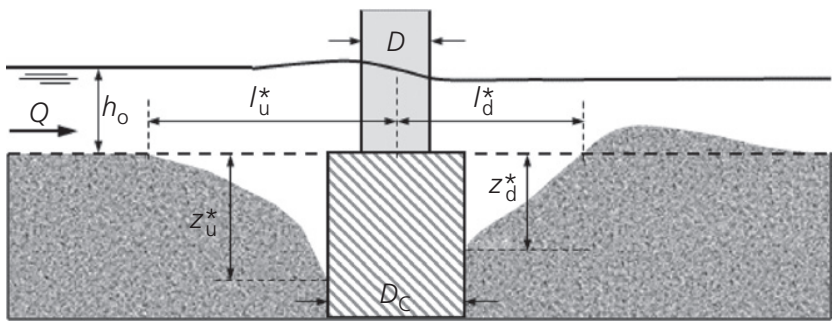

(b)

Figure 2. Schematic illustration of physical models and definition of symbols: (a) pile-founded pier; (b) caisson-founded pier 


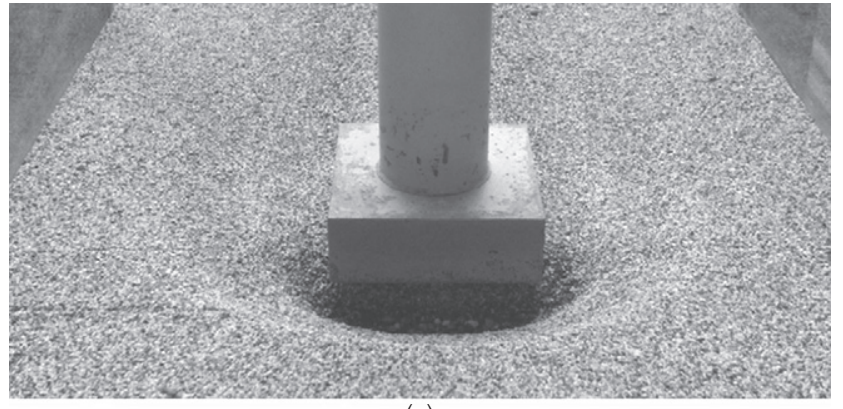

(a)

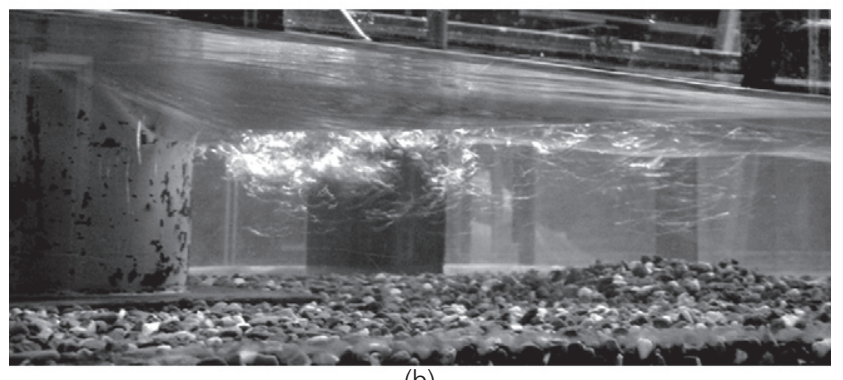

(b)

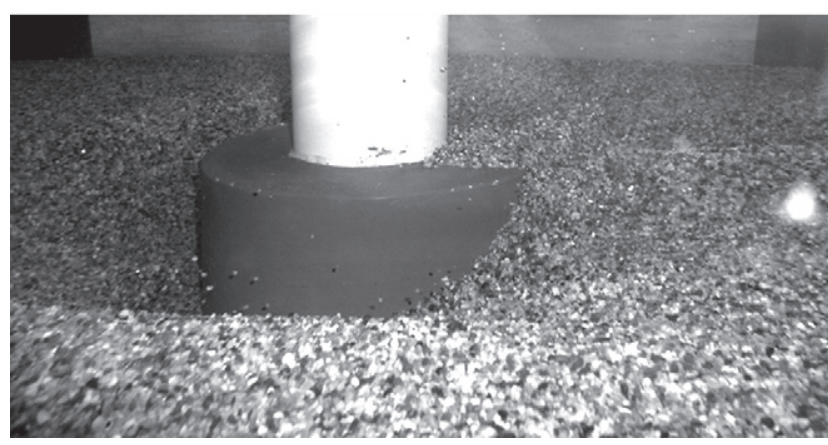

(c)

Figure 3. (a) Bed morphology at the experiment end for the run PP5 with piled-founded pier (view from upstream). (b) Wake region and sediment mound during run PP12 (lateral view, flow is from left to right). (c) Scouring process during run CP5 (lateral view, flow is from left to right)

where weak live-bed conditions occurred. The majority of the runs were of long duration (up to $11 \mathrm{~d}$ ) to ensure sufficient interaction between the flow and the complex pier footing, well-developed scour holes and an approach to the equilibrium phase. Figure 3 shows typical scour hole morphology for two runs with a sandy bed and water features in the wake region of pier in gravel bed.

The water discharge was measured to an accuracy of $\pm 3 \%$ by means of an orifice plate installed in the circuit. The water surface was measured using a conventional point gauge with accuracy to the nearest millimetre and the sediment surface was measured to an accuracy of the order of the grain size by means of a shoe gauge with a $4 \mathrm{~mm}$ by $2 \mathrm{~mm}$ wide horizontal plate at its base. Detailed measurements of the bed morphology (typically around 1000 bed-level data) were made during and at the end of each run. An adjustable sharp-crested weir located at the end of the channel controlled the approach flow depth. Once the bed was carefully levelled, the channel was slowly filled to avoid any sediment movement by submerging the working section with the weir. The water discharge was then slowly increased to the preselected value. The experiment started when the approach flow depth was set to the preselected value by lowering the weir. Table 1 (provided as supplementary data to this paper) gives the main conditions of each run: $Q$ is the discharge, $h_{\mathrm{o}}$ is the approach flow depth, $\mathrm{F}_{\mathrm{d}}=V /\left(\boldsymbol{g}^{\prime} d_{50}\right)^{1 / 2}$ is the densimetric Froude number at the approach section ( $V$ is cross-sectional flow velocity, $\boldsymbol{g}^{\prime}=\boldsymbol{g}\left(\rho_{\mathrm{s}}-\rho\right) / \rho$ is the modified gravitational acceleration, $\rho$ is mass density of water and $\boldsymbol{g}$ is gravitational acceleration), $\mathrm{F}_{\mathrm{di}}$ is the inception densimetric Froude number as defined by Hager and Oliveto (2002), $t$ is time from the start of the run, $z_{\mathrm{u}}^{*}$ is the scour depth at the front of the foundation, $z_{\mathrm{d}}^{*}$ is the scour depth at the rear of the foundation, $l_{\mathrm{u}}^{*}$ is the scour hole length from the pier vertical axis to the upstream edge of scour hole, $l_{\mathrm{d}}^{*}$ is the scour hole length from the pier vertical axis to the downstream edge of scour hole and $\Lambda$ is the scour hole volume at given time $t$. Measurements for the hole geometry are at the channel axis.

Figure 4 shows contour maps at different times of the bed morphology around the caisson-founded pier for two different runs, one with the sandy bed and the other with the gravelly bed. Local bed morphology developed differently depending on the sediment grain size. In the case of sand (Figure 4(a)), at the earlier scour stages, the maximum scour depth occurred at the sides of the caisson and afterwards at the caisson front. In the case of gravel (Figure 4(b)), the scour area initially developed in the wake region and then slightly propagated upwards due to regressive erosion. A possible reason for this difference could be that, for the given pier and approach flow conditions, different water-surface profiles were generated around the pier depending on the type of sediment bed. Energy losses increased as grain size increased, which implies an increasing drop in water surface from just upstream of the pier to just downstream of the pier with increasing grain size, as observed in this experimental work. Thus, for the given pier and approach flow conditions, the water depth downstream of the pier was smaller in the case of gravel than for sand and the beginning of scour hole development occurred in the wake region.

\section{Analysis of data}

The presented analysis is first focused on a comparison of the data collected in the present study with the HEC-18 methodology, which applies to equilibrium scour conditions. The data are then interpreted in light of the formula presented by Oliveto and Hager (2002) for the temporal variation of maximum scour depth around uniform cylindrical piers. Finally, a new predictive formula accounting for the effects of the foundation is introduced. 


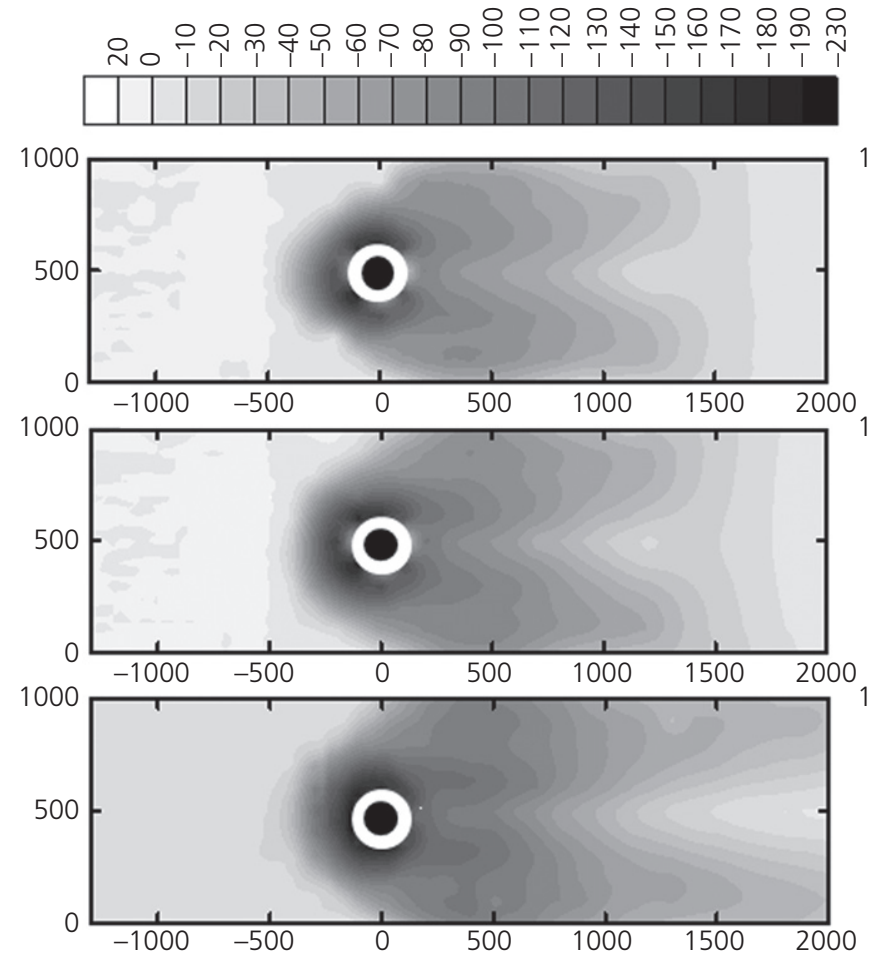

(a)

Figure 4. Contour maps at different times of the bed morphology around the caisson-founded pier for run (a) CP5 with sand and (b) run CP7 with gravel. Graphs from top to bottom
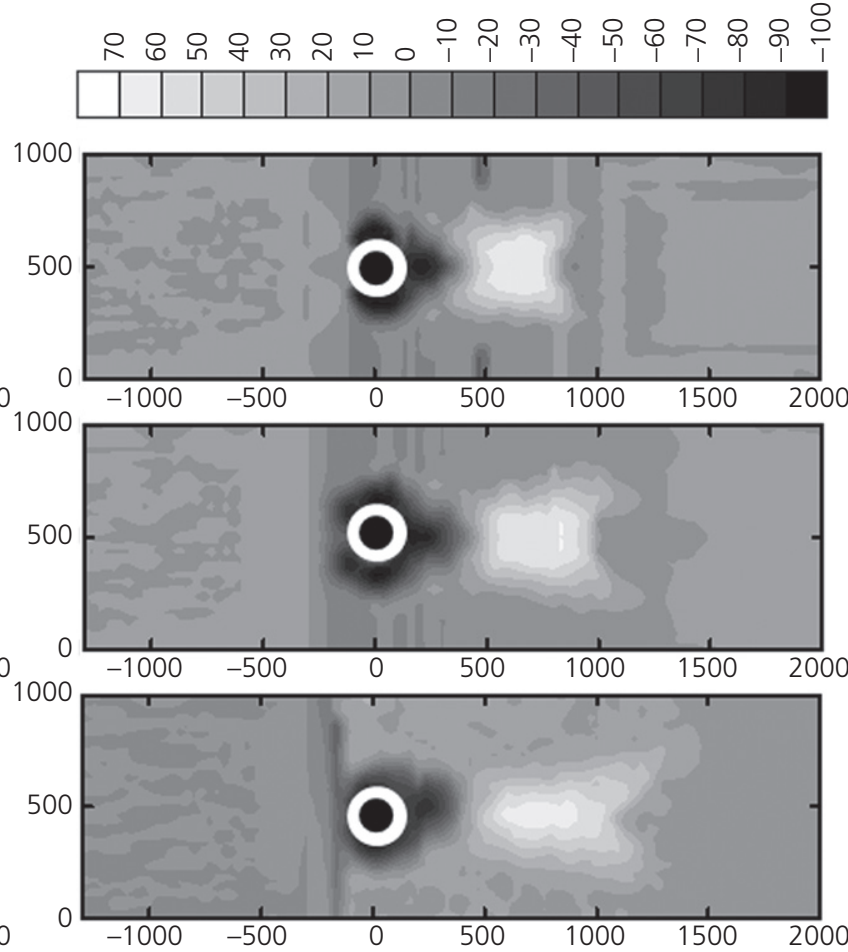

(b)

refer to $t=24,48$ and $72 \mathrm{~h}$ for run CP5 and $t=4,24$ and $72 \mathrm{~h}$ for run $\mathrm{CP7}$. Axis coordinates and measurements are in millimetres

\subsection{Comparison with HEC-18 methodology}

The HEC-18 methodology (Arneson et al., 2012) implies the superposition of scour components including the scour depths caused by the pier stem, the pile cap and the pile group in the case of pile-founded piers and the pier stem and the caisson in the case of caisson-founded piers. The procedures for estimating scour depths for isolated components are described in detail by Arneson et al. (2012).

Figure 5(a) shows the ratio of computed scour depth according to the HEC-18 methodology to the observed scour depth $\left(\psi_{\mathrm{HEC}-18}\right)$ from the experiments of the present study as a function of a dimensionless time $T$ (defined later). Runs with gravel beds (i.e. runs P2, P3, PP10-PP12 and CP7) were not considered because the HEC-18 pier scour equation applies to flow situations in alluvial sand bed channels.

It can be observed that predictions are satisfactorily accurate for run P1 with a uniform cylindrical pier. This result is consistent with the fact that run P1 was of long duration and equilibrium conditions were almost attained. In general, the predictions are conservative for runs with non-uniform piers, with overestimations that are moderate for $T>10^{5}$ but could be significant ( $\psi_{\text {HEC-18 }}$ up to 5 ) for $T<10^{5}$. The HEC-18 methodology appears to be suitable for predicting the equilibrium scour depth at both uniform and non-uniform piers. On the other hand, it could lead to considerable overestimation for floods of short duration or when unsteady flow conditions are considered.

\subsection{Comparison with uniform cylindrical piers}

The formula proposed by Oliveto and Hager (2002) for temporal variation of scour at uniform cylindrical piers was considered for a comparison of uniform and non-uniform piers. According to Oliveto and Hager (2002), the maximum scour depth $z$ depends on three main parameters - the reference length $D^{2 / 3} h_{\mathrm{o}}^{1 / 3}$, the densimetric Froude number $\mathrm{F}_{\mathrm{d}}$ and the relative time $T=\left[\sigma^{1 / 3}\left(g^{\prime} \mathrm{d}_{50}\right)^{1 / 2} /\left(D^{2 / 3} h_{\mathrm{o}}^{1 / 3}\right)\right] t$

1. $Z=0.068 \sigma^{-0.5} \mathrm{~F}_{\mathrm{d}}^{1.5} \log T$

where $D$ is the pier diameter and $Z=z /\left(D^{2 / 3} h_{\mathrm{o}}^{1 / 3}\right)$. Equation 1 applies for $0.6 \leq \mathrm{F}_{\mathrm{t}} \leq 1.0$ where $\mathrm{F}_{\mathrm{t}}=\mathrm{F}_{\mathrm{d}} / \mathrm{F}_{\mathrm{di}}$ is the so-called threshold Froude number (Oliveto and Hager, 2002).

Figure 5(b) shows the ratio $\left(\psi_{\mathrm{OH}}\right)$ of observed to computed scour depths according to the Oliveto and Hager (2002) formula. A few experimental data points were not considered because $F_{t}$ was definitely lower than $0 \cdot 6$. Some experiments 


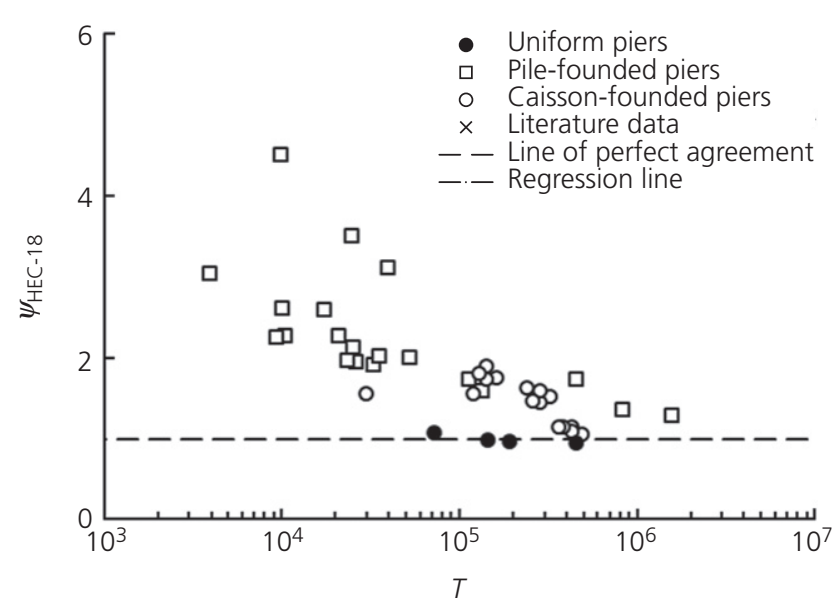

(a)

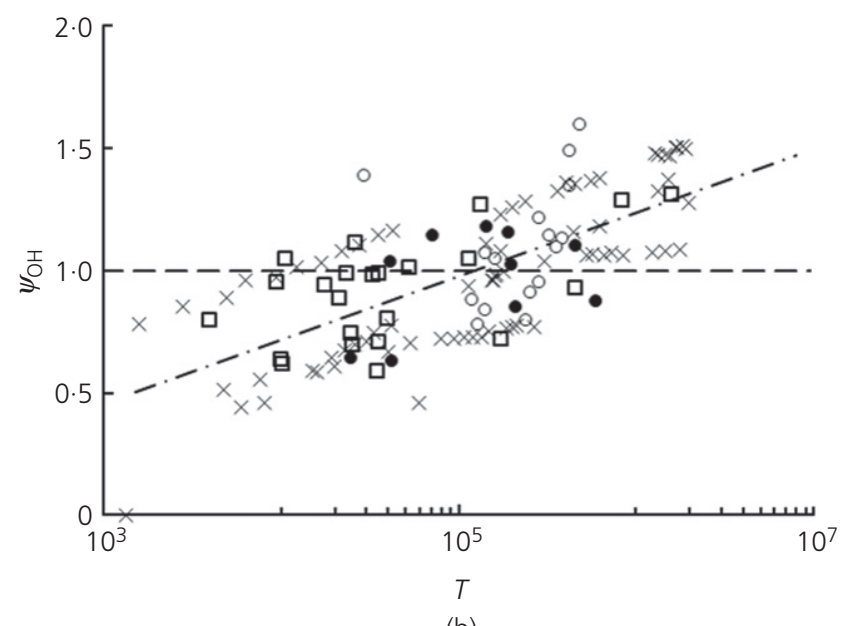

(b)

Figure 5. (a) Ratio $\psi_{\mathrm{HEC}-18}$ of computed to observed scour depths according to HEC-18 methodology as a function of $T$. (b) Ratio $\psi_{\mathrm{OH}}$ of observed to computed scour depths according to Equation 1 as a function of $T$

from the literature were also considered, namely series D from Melville and Raudkivi (1996), runs 2 and 8 from Oliveto et al. (2006), run 10 from Kothyari and Kumar (2012) and test A5 from Ferraro et al. (2013). In test A5 the non-uniform pier consisted of a rectangular column with a rounded upstream and downstream end, founded on a rectangular pile cap with a rounded nose and tail, and supported by an array of piles. For this test, the maximum width transversal to the flow direction for the rectangular column and pile cap was considered as $D$ and $W_{\text {PC }}$ values, respectively.

The observed data for uniform cylindrical piers agree satisfactorily with the predictions from Equation 1. In general, the deviations are within $\pm 25 \%$, as suggested by Oliveto and Hager (2002), independent of the bed material. Incidentally, the morphological evolution of the sediment mound downstream of the pier was also found to be in satisfactory agreement with the predictions of Oliveto and Hager (2014). The overall data trend reveals a different development of the scour process between non-uniform and uniform piers. In the case of non-uniform piers, shielding effects by the foundation would occur for $T$ less than about $10^{5}$ while, for $T>10^{5}$, an amplification of scour depths would occur due to the wider effective width of the pier when the foundation becomes exposed to the flow. The dispersion of the data can be explained by the different types of foundations and, especially, by the pier to foundation width ratios. Specifically, when comparing the observed and computed scour depths, the coefficient of determination $R^{2}$ (and the standard error of the estimate $(\mathrm{SE}))$ was $0.86(\mathrm{SE}=0.018 \mathrm{~m}), 0.81(\mathrm{SE}=0.018 \mathrm{~m})$ and $0.72(\mathrm{SE}=0.029 \mathrm{~m})$ for uniform, pile-founded and caisson-founded piers, respectively. It should also be noted that the measurement accuracy was of the order of the grain size for all the experimental data considered in this study.

\subsection{Predictive scour equation}

Based on previous considerations, the following equation is proposed to estimate the maximum scour depth $z^{*}$ at non-uniform piers when the foundation top is at the initial bed level

2. $Z^{*}=\left(\frac{D_{\mathrm{C}}}{D}\right) 0.068 \sigma^{-0.5} \mathrm{~F}_{\mathrm{d}}^{1.5} \log \left(\frac{T}{T^{*}}\right)$ for $T \geq T^{*}$

with $Z^{*}=z^{*} /\left(D^{2 / 3} h_{\mathrm{o}}^{1 / 3}\right)$.

Equation 2 refers to caisson-founded piers, but it also applies to pile-founded piers with a square pile cap when substituting $W_{\mathrm{PC}}$ for $D_{\mathrm{C}} . T^{*}$ is a characteristic dimensionless time representing the $T$-threshold when scour starts. In this study, $T^{*}$ was found to be equal to $10^{2\left(D_{\mathrm{C}} / D-1\right)}$ or $10^{2\left(W_{\mathrm{PC}} / D-1\right)}$ from regression analysis. The foundation effect was also incorporated into Equation 2 through the factor $\left(D / D_{\mathrm{C}}\right)^{\alpha}$, which is consistent with the condition $\left(D / D_{\mathrm{C}}\right)^{\alpha}=1$ when $D_{\mathrm{C}}=D . \alpha=0.90$ was found by minimising data scattering, but $\alpha=1 \cdot 0$ was assumed to make the model slightly conservative. So, the beginning of the scour development is postponed compared with uniform piers with a delay that increases as $D_{\mathrm{C}} / D$ (or $W_{\mathrm{PC}} / D$ ) increases. It should also be noted that Equation 2 is consistent with the condition that $Z^{*}=Z$ for $D / D_{\mathrm{C}}=1$ or $D / W_{\mathrm{PC}}=1$ (i.e. a uniform pier) and $Z^{*} \rightarrow 0$ as $D_{\mathrm{C}}$ or $W_{\mathrm{PC}} \rightarrow \infty$ because scour would start to develop as $T^{*} \rightarrow \infty$. Moreover, the scour rate is higher than that of uniform piers and increases as $D_{\mathrm{C}} / D$ (or $\left.W_{\mathrm{PC}} / D\right)$ increases.

Figure 6 shows a comparison of Equation 2 and the same experimental data used in Figure 5(b). The observations agree satisfactorily with the predictions, with deviations overall within $\pm 25 \%$. Specifically, when comparing the observed and computed scour depths, $R^{2}$ (and $\mathrm{SE}$ ) was $0.86(\mathrm{SE}=0.018 \mathrm{~m}$ ), $0.66(\mathrm{SE}=0.032 \mathrm{~m})$ and $0.84(\mathrm{SE}=0.028 \mathrm{~m})$ for uniform, pilefounded and caisson-founded piers, respectively. Overall, these 


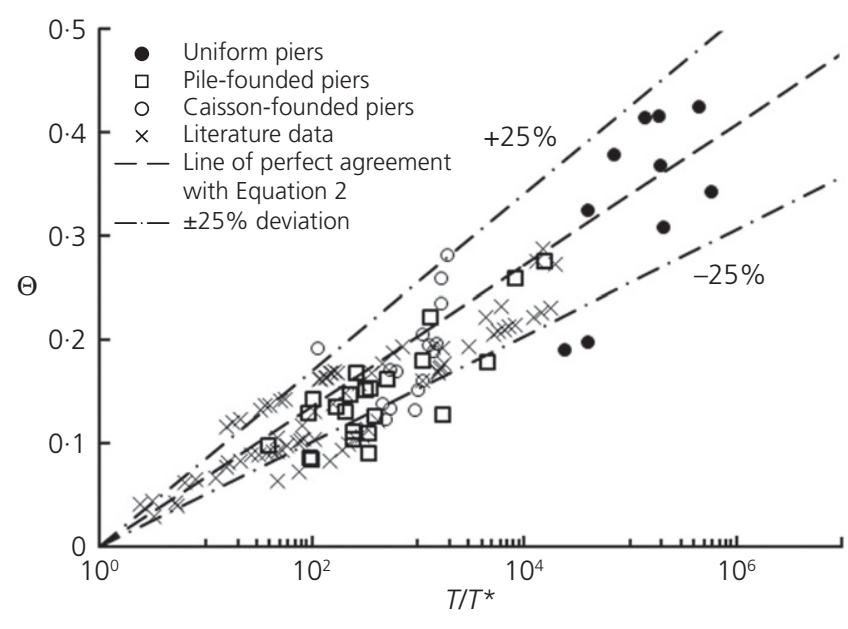

Figure 6. Dimensionless group $\Theta=Z^{*} /\left[\left(D_{C} / D\right) \sigma^{-0.5} \mathrm{~F}_{\mathrm{d}}^{1 \cdot 5}\right]$ or $Z^{\star} /\left[\left(W_{\mathrm{PC}} / D\right) \sigma^{-0.5} \mathrm{~F}_{\mathrm{d}}^{1.5}\right]$ as a function of $T / T^{*}$

values are suitable even though they are conditioned by the fact that Equation 2 is slightly conservative. However, data scattering is definitely lower than that in Figure 5(b). The effect of the foundation shapes considered in this analysis can be considered negligible, although a pile cap appears to be slightly more protective than a circular caisson at the earlier scour stages.

Equation 2 applies to sand- and gravel-bed rivers under a clearwater regime. The ranges of applicability are $0.46 \leq F_{t} \leq 1 \cdot 02$, $1 \cdot 31 \leq \mathrm{F}_{\mathrm{d}} \leq 3 \cdot 55, \quad 15 \cdot 6 \leq h_{\mathrm{o}} / d_{50} \leq 250 \cdot 0, \quad 0 \cdot 64 \leq h_{\mathrm{o}} / D \leq 6 \cdot 67$, $1 \cdot 9 \cdot 10^{2} \leq T \leq 2 \cdot 0 \cdot 10^{6}$ and $0 \cdot 33 \leq D / D_{\mathrm{C}} \quad\left(\right.$ or $\left.\quad D / W_{\mathrm{PC}}\right) \leq 1 \cdot 00$. Typical conditions of a clear-water regime (or low sediment transport) could be flows over floodplains (especially when they are grassed) and also during floods, flat bed slopes during low flows and coarse-bed rivers especially with natural vegetation or artificial reinforcements. However, it is well known that, for uniform piers, the maximum local clear-water scour depth is typically $10 \%$ larger than the maximum local live-bed scour depth. Thus, clear-water scour conditions can also be considered to estimate approximately the local scour under live-bed conditions.

Moreover, Equation 2 applies to conditions in which the (square) pile cap is aligned to the flow direction in the case of pile-founded piers while it can be applied independently of flow patterns in the case of (cylindrical) piers founded on (cylindrical) caissons.

Equation 2 allows scour depth estimations taking time effects into account. To this aim, the following data are needed complex pier geometry, sediment bed characteristics $\left(d_{50}\right.$ and $\sigma$ ), approach flow depth $h_{\mathrm{o}}$, approach flow velocity $V_{\mathrm{o}}$ and peak flood duration. Moreover, Equation 2 could also be applied taking the entire flood hydrograph into account. In this case, the approach suggested by Oliveto and Hager (2005) for unsteady flow could be used.

Finally, the proposed approach also appears promising for different elevations of the foundation from the streambed. For instance, let us consider the condition where the foundation top is above the initial bed level. Let us also define $Y$ as the foundation top elevation measured from the initial bed level (positive when the foundation top is above the bed level). Equation 2 applies to the condition $Y=0$, but it would also appear to be able to contemplate conditions with $Y>0$. In these cases, for instance, an equivalent pier diameter $D_{\text {eq }}$ can be used as a substitute for the pier diameter $D$, with $D_{\text {eq }}=D\left(D_{\mathrm{C}} / D\right)^{Y / h_{\mathrm{o}}}\left(0 \leq Y / h_{\mathrm{o}} \leq 1\right)$. It can be noted that $D_{\text {eq }}=D$ when $Y / h_{\mathrm{o}}=0$ while $D_{\mathrm{eq}}=D_{\mathrm{C}}$ when $Y / h_{\mathrm{o}}=1$.

\section{Conclusions}

Laboratory experiments on local scour around non-uniform piers were carried out at the Hydraulic Engineering Laboratory, University of Basilicata, Italy. To explore the temporal variation of the local bed morphology in comparison with uniform cylindrical piers, runs lasted from 1 to $271 \mathrm{~h}$. The main results can be summarised as follows.

- Experimental data were compared with the predicted values according to the HEC-18 approach (Arneson et al., 2012) for complex pier foundations. The results revealed that the HEC-18 methodology is suitable for scour prediction at the equilibrium stage, but could lead to significant overestimations when more realistic conditions of unsteady flow are considered.

- Observed data were also compared with the predicted values according to the formula presented by Oliveto and Hager (2002) for uniform piers. The results showed a different development of the scour process for non-uniform and uniform piers. Shielding effects by the pier foundation occurred for dimensionless time $T$ less than about $10^{5}$ while an amplification of scour depths due to the wider effective width of the pier occurred for $T>10^{5}$.

- A new predictive scour equation (Equation 2) was proposed. This formula is a generalisation of the formula suggested by Oliveto and Hager (2002) for the temporal evolution of scour depth at uniform piers. It satisfactorily describes the experimental observations from this study and some other data from the literature. The ranges of applicability are $0 \cdot 46 \leq \mathrm{F}_{\mathrm{t}} \leq 1 \cdot 02,1 \cdot 31 \leq \mathrm{F}_{\mathrm{d}} \leq 3 \cdot 55$, $15 \cdot 6 \leq h_{\mathrm{o}} / d_{50} \leq 250 \cdot 0,0 \cdot 64 \leq h_{\mathrm{o}} / D \leq 6 \cdot 67$, $1 \cdot 9 \cdot 10^{2} \leq T \leq 2 \cdot 0 \cdot 10^{6}$ and $0 \cdot 33 \leq D / D_{\mathrm{C}}\left(\right.$ or $\left.D / W_{\mathrm{PC}}\right) \leq 1 \cdot 00$.

This paper aimed to provide some new insights into a process that is controlled by numerous variables. However, more research studies are needed, mainly considering different sediment beds, pier foundation geometries and the condition of foundations exposed to flow owing to general scour. 


\section{REFERENCES}

Amini A, Melville BW and Ali TM (2014) Local scour at piled bridge piers including an examination of the superposition method. Canadian Journal of Civil Engineering 41(5): 461-471.

Amini AS, Mohammad TA, Aziz AA, Ghazali AH and Huat BBK (2011) A local scour prediction method for pile caps in complex piers. Proceedings of the Institution of Civil Engineers - Water Management 164(2): 73-80, http://dx.doi.org/10.1680/wama.900064.

Arneson LA, Zevenbergen LW, Lagasse PF and Clopper PE (2012) Evaluating Scour at Bridges. Federal Highway Administration, Washington, DC, USA, Report FHWAHIF-12-003 HEC-18.

Ataie-Ashtiani B, Baratian-Ghorghi Z and Beheshti AA (2010) Experimental investigation of clear-water local scour of compound piers. Journal of Hydraulic Engineering ASCE 136(6): 343-351.

Chabert J and Engeldinger P (1956) Étude des affouillements autour des piles de ponts. Laboratoire National d'Hydraulique Série A, Chatou, France (in French).

Chang WY, Constantinescu G, Lien HC et al. (2013) Flow structure around bridge piers of varying geometrical complexity. Journal of Hydraulic Engineering ASCE 139(8): 812-826.

Chreties C, Teixeira L and Simarro G (2013) Influence of flow conditions on scour hole shape for pier groups. Proceedings of the Institution of Civil Engineers - Water Management 166(3): 111-119, http://dx.doi.org/10.1680/wama.11.00054.

Coleman SE (2005) Clearwater local scour at complex piers. Journal of Hydraulic Engineering ASCE 131(4): 330-334.

Ferraro D, Tafarojnoruz A, Gaudio R and Cardoso AH (2013) Effects of pile cap thickness on the maximum scour depth at a complex pier. Journal of Hydraulic Engineering ASCE 139(5): 482-491.

Hager WH and Oliveto G (2002) Shields' entrainment criterion in bridge hydraulics. Journal of Hydraulic Engineering ASCE 128(5): 538-542.

Jones SJ, Kilgore RT and Mistichelli MP (1992) Effects of footing location on bridge pier scour. Journal of Hydraulic Engineering ASCE 118(2): 280-290.

Jones SJ, Kilgore RT and Mistichelli MP (1993) Closure to 'Effects of footing location on bridge pier scour'. Journal of Hydraulic Engineering ASCE 119(2): 299-300.

Kothyari UC and Kumar A (2012) Temporal variation of scour around circular compound piers. Journal of Hydraulic Engineering ASCE 138(11): 945-957.

Kothyari UC, Garde RJ and Raju KGR (1992) Temporal variation of scour around circular bridge piers. Journal of Hydraulic Engineering ASCE 118(8): 1091-1106.

Kumar A and Kothyari UC (2012) Three-dimensional flow characteristics within the scour hole around circular uniform and compound piers. Journal of Hydraulic Engineering ASCE 138(5): 420-429.

Lu JY, Shi ZZ, Hong JH, Lee JJ and Raikar RV (2011) Temporal variation of scour depth at nonuniform cylindrical piers. Journal of Hydraulic Engineering ASCE 137(1): 45-56.
Martín-Vide JP, Hidalgo C and Bateman A (1998) Local scour at piled bridge foundations. Journal of Hydraulic Engineering ASCE 124(4): 439-444.

Melville BW (1993) Discussion on 'Effects of footing location on bridge pier scour'. Journal of Hydraulic Engineering ASCE 119(2): 296-298.

Melville BW and Coleman SE (2000) Bridge Scour. Water Resources Publications, Highlands Ranch, CO, USA.

Melville BW and Raudkivi AJ (1996) Effects of foundation geometry on bridge pier scour. Journal of Hydraulic Engineering ASCE 122(4): 203-209.

Moreno M, Maia R and Couto L (2016) Effects of relative column width and pile-cap elevation on local scour depth around complex piers. Journal of Hydraulic Engineering ASCE 142(2): 04015051.

Oliveto G and Hager WH (2002) Temporal evolution of clear-water pier and abutment scour. Journal of Hydraulic Engineering ASCE 128(9): 811-820.

Oliveto G and Hager WH (2005) Further results to time-dependent local scour at bridge elements. Journal of Hydraulic Engineering ASCE 131(2): 97-105.

Oliveto G and Hager WH (2014) Morphological evolution of dune-like bed forms generated by bridge scour. Journal of Hydraulic Engineering ASCE 140(5): 06014009.

Oliveto G, Onorati B and Comuniello V (2006) Effects of pile caps on local scour at bridge piers. Proceedings of the 3rd International Conference on Scour and Erosion-ICSE 3, Amsterdam, The Netherlands. CURNET, Gouda, The Netherlands, CD-Rom.

Parola AC, Mahavadi SK, Brown BM and El Khoury A (1996) Effects of rectangular foundation geometry on local pier scour. Journal of Hydraulic Engineering ASCE 122(1): 35-40.

Sheppard DM and Glasser T (2009) Local scour at bridge piers with complex geometries. In Contemporary Topics in In Situ Testing, Analysis, and Reliability of Foundations (Iskander M, Laefer DF and Hussein MH (eds)). American Society of Civil Engineers, Reston, VA, USA, Geotechnical Special Publication, vol. 186, pp. 506-513.

Veerappadevaru G, Gangadharaiah T and Jagadeesh TR (2011) Vortex scouring process around bridge pier with a caisson. Journal of Hydraulic Research IAHR 49(3): 378-383.

\section{HOW CAN YOU CONTRIBUTE?}

To discuss this paper, please email up to 500 words to the editor at journals@ice.org.uk. Your contribution will be forwarded to the author(s) for a reply and, if considered appropriate by the editorial board, it will be published as discussion in a future issue of the journal.

Proceedings journals rely entirely on contributions from the civil engineering profession (and allied disciplines). Information about how to submit your paper online is available at www.icevirtuallibrary.com/page/authors, where you will also find detailed author guidelines. 